\title{
Model Of Partnership Agreement Between Medium Small Businesses (Smes) And Big Businesses In Realizing Joint Welfare
}

\author{
Rai Mantili \\ Universitas Padjadjaran, Bandung-Indonesia \\ rai@unpad.ac.id
}

Published: 28/02/2020

How to cite:

Mantili, R. 2020. Model Of Partnership Agreement Between Medium Small Businesses (Smes) And Big Businesses In Realizing Joint Welfare. Sociological Jurisprudence Journal. Volume 3 Issue 1. Page 28 -33. https://doi.org/10.22225/scj.3.1.1514.28-33

\begin{abstract}
The objectives of this study is to examine the partnership agreement model between SMEs and Large Enterprises in creating shared prosperity and to examine the principles' application of the agreement in partnership that can provide protection for SMEs in Indonesia. The research method used in this study is analytical descriptive which aims to obtain a comprehensive picture of the partnership agreement in Indonesia. Data about the business partnership agreement and its implementation are then analyzed to answer the research problem. Based on analysis, the results of this study showed that 1) the partnership agreement model between SMEs and Large Enterprises in creating shared prosperity must begin with efforts to apply the principles of the agreement and business ethics in the partnership agreement. 2) the application of the principles of agreement in partnership in practice has not yet run optimally, there are still many partnership agreements that have been deviated from the contents of the agreement. In this case the role of government is needed to provide protection to the SME group and also the Large Business group to realize social responsibility for the progress of the UKM business group.
\end{abstract}

Keywords: Large Enterprises, Partnership Agreements, SMEs

\section{INTRODUCTION}

As an integral part of the national business world, Small and Medium Enterprises (SMEs) have a very important and strategic position, potential and role. SMEs are proven to be able to expand employment opportunities and provide broad economic services to the community. The SME group has several advantages and advantages compared to the Large Business group, among others viz (Mubyarto, 2001):

SMEs are able to absorb large numbers of workers. In addition, SMEs are one of the sectors that touch and favor the majority of the population.

SMEs are relatively not based on imported raw materials (low import content), but are based on local raw materials.

SMEs rely on appropriate technology, not on high technology that is capital intensive.

SMEs are proven to be resistant to shocks in the economic crisis. Based on a survey conducted by the Asian Development Bank Technical Assistance (ADB-TA) during the economic crisis, it is known that 78 percent of SMEs surveyed were not negatively affected by the economic crisis.

Based on research, there is almost never a Large Business group that has a relationship with SMEs. There are some who have a relationship but in a position that is not parallel. Theoretically, the partnership agreement is considered to be very ideal and able to solve the problems faced by the people of the people's economy, ranging from capital, technology and marketing problems. However, in implementing the partnership agreement there were still many obstacles and some even looked at the implementation of the business partnership being felt to be not optimal. 
Not yet optimal implementation of the business partnership agreement between SMEs and Large Enterprises is also suspected to be due to non-compliance with the normative rules of the agreement as regulated in Book III of the Civil Code. Article 1319 of the Civil Code states that all agreements, whether they have a specific name or are not known by a certain name, must comply with the general rules contained in this chapter (Chapter II) and the previous chapter (Chapter II) of the Civil Code. Partnership as a form of agreement in addition to having to refer to general teachings and commitments, must also refer to and base its working mechanism on the principles of religious, moral, and justice teachings. In practice, several cases were found in the pattern of partnerships in the field of agribusiness, which caused farmers to suffer losses due to partnership agreements that deviated from the contents of the agreement. The core company sets prices unilaterally, determining the quality (grade) of the commodity. In the subcontractor partnership pattern, small business groups (recipients of orders) are often victims of being exploited by large businesses, ranging from unilateral pricing, too long a payment system to product rejection without the support of strong reasons. Therefore, legal protection efforts in partnerships are not negotiable. Legal protection in partnership is a lengthy process that begins at the time of the pre-contract (before the agreement is made) until the post-production activities, so that at each stage of the partnership there are no deviations and proceed as desired. Referring to one of the principles of national engagement law formulated by the National Legal Development Agency (BPHN), the business partnership agreement must also adhere to the principle of protection. The principle of protection implies that each partner must be protected by law, especially UKM groups because they are generally on the weak side.

Some latest related studies have been conducted previously by some researcher, such as (Nugroho, Sulistyowati, \& Hikmah, 2017) that carried out the study entitled "A juridical review of partnership agreements that have the elements of work agreements in Indonesia". The aims of this research is, 1) to know whether the Partnership Agreement whose substance includes the elements of wages and orders can be categorized as Work Agreement and 2) to know which courts are authorized to adjudicate the disputes of the parties in Partnership Agreement whose substance there is an element of command and wages. Based on the analysis, the results of this study showed that Partnership Agreement of which the elements are: wages and orders can be categorized as Work Agreement. Moreover in case there is a dispute concerning the Partnership Agreement in which the elements are: wages and orders, the authorized court is Industrial Relations Court as stated by Article 57 of Law Number 2 Year 2004 Concerning Industrial Relations Dispute Settlement. Besides that, (Mulhadi \& Sembiring, 2019) also conducted the similar study entitled "Legal Characters of Partnership Agreement 212 Mart". This study aims to determine the legal character of the business partnership agreement establishing 212 Mart Supermarkets. The results of this study showed that partnership agreement 212 Mart has several legal characters namely that partnership agreement 212 mart was identified as an unnamed (anonymous) agreement, reciprocal agreement, as an agreement which gave birth to new partnerships, and jamaatbased agreements.

Based on the background that has been described above, the objectives of this study is to examine the partnership agreement model between SMEs and Large Enterprises in creating shared prosperity and to examine the principles' application of the agreement in partnership that can provide protection for SMEs in Indonesia.

\section{METHOD}

The research method used in this study is analytical descriptive which aims to obtain a comprehensive picture of the partnership agreement in Indonesia. Data about the business partnership agreement and its implementation are then analyzed to answer the research problem. The approach used in this research is normative research which focuses research on library data, or secondary data through legal principles, rules/norms of business competition law and civil procedural law (Soemitro, 1980) and research in concreto. The approach through legal principles is a study of legal norms which are the benchmarks for proper behavior (Soekanto \& Mamudji, 1995). In accordance with the approach method used, the study is conducted on the norms and principles contained in secondary data, which are spread in primary, secondary, and tertiary legal material. This includes a study of the ius consitutum related to the object of research and formulating the ius constituendum as an ideal norm that must be realized.The research stages in this study are as follows: Legal material research, covering: 1) Primary legal material 
in the form of positive law, namely the 1945 Constitution, Civil Code, Government Regulation No. 44 of 1997 concerning Partnerships, Law No. 9 of 1995 concerning Small Businesses, Law No. 20 of 2008 concerning Micro, Small and Medium Enterprises. 2) Secondary legal materials are materials that are closely related to primary legal materials, including the literature in the field of Small Business Law, Large Business, agreements and partnerships. 3) Tertiary legal material is material that provides information about primary and secondary legal materials, including articles, magazines, newspapers, internet browsing related to partnership agreement issues. Drawing conclusions from the results of research that has been collected is done by qualitative normative analysis methods. Normative because research starts from the existing regulations as positive law, principles of law, and understanding of law.

\section{III.RESULT AND DISCUSSION}

Based on the objectives and the study that carried out, thus it obtained the results of the study that can be described in the following discussion.

\section{Model partnership agreement between SMEs and Large Enterprises in creating shared prosperity}

Article 1 paragraph (1) Government Regulation No. 44 of 1997 concerning Partnership states that a partnership is a collaboration of Small Business with Medium Business and or with Large Business accompanied by Medium Business and or Large Business by observing the principle of mutual need, mutual strengthening and mutual benefit. Partnership in the context of business linkages is implemented through business partnership agreement patterns that are in accordance with the nature and objectives of the business being partnered with as many opportunities of partnership as possible for the Small Business by the government and the business world. Consideration of Government Regulation No. 44 of 1997 concerning Partnership categorizes partnerships as an agreement, even though it has specific goals and objectives, namely revolving around the development and development of businesses by paying attention to the principles of mutual need, mutual reinforcement, and mutual benefit, to accelerate the realization of an independent national economy in order to advance the structure national economy.

Partnership can be categorized as a partnership agreement (maatschap) as regulated in Articles 16181652 of the Civil Code. Partnership is the agreement of several people to cooperate in the economic field with the aim of sharing the benefits to be gained. Maatschap is the simplest form of cooperation agreement, there are no specific capital requirements, even one of the parties is allowed to only contribute its energy. Arrangements for mutual benefit sharing, regulated in the agreement to establish a maatschap. The maatschap agreement is not required to be made in a particular deed or form. Oral agreements are allowed. An agreement that is not required in a particular form or manner, is called a consensueel agreement, meaning that it is sufficient if there is an agreement (Subekti, 1984).

Partnerships can be categorized as "nameless agreements", ie agreements that are not regulated in the Civil Code, but are in the community. The number of these agreements is unlimited with names that are adjusted to the needs of the parties who made them. The birth of this agreement in practice is based on the principle of freedom of contract. Named agreements are agreements that have not yet been specifically regulated by law (Satrio, 2001).

Business partnership is a series of processes that begin by getting to know potential partners, knowing the strengths and weaknesses of their business. Understanding of existing advantages will produce synergies that have an impact on efficiency, lower production costs and so on. That way, large companies can save energy in achieving certain targets by using the workforce that is owned by small companies. Conversely, smaller companies, which are generally relatively weak in terms of technological capabilities, capital and production facilities through technology and production facilities owned by large companies. Thus, Mariotti describe there is actually a relationship of mutual need or dependency between the two partners (Hafsah, 1999).

Article 29 of Law No. 9 of 1995 concerning Small Business and Government Regulation No. 47 of 1997 concerning Partnership stipulates that partnership relations are set forth in the form of a written agreement that at least regulates the form and scope of partnership business activities, the rights and obligations of each party, the form of coaching and development, as well as the period and dispute resolution. The rights, obligations and responsibilities of the parties to the partnership are specifically regulated in a written agreement that must be made by the parties. However, in general Article 12 to 
Article 18 of Government Regulation No. 44 of 1997 concerning Partnership regulates the rights and obligations of the parties to the partnership.

As one form of agreement, the partnership is also bound and must base its mechanism of action on the ethical basis of the agreement "pacta sunt servanda" which means "the promise is binding". Partnership is also bound by the principles of religion and morality that are an inherent part of an agreement. In today's modern legal system, freedom of contract is not only limited by restrictions created by statutory prohibitions, but also by extra legal standards (Khairandy, 2004).

Like agreements in general, in addition to having to pay attention to the provisions contained in Book III of the Civil Code, partnerships must also pay attention to the principles contained in the law of agreement in general. Namely: the principle of freedom of contract (freedom of Contract, contracvrijheid), the principle of consensualism, the principle of Pacta Sunt Servanda (the principle of binding power), the principle of good faith (Goede Trouw, Good Faith), and the principle of personality (Personality). Apart from having to be based on these principles, partnership agreements also need to pay attention to the principles: Equality Principle, Principles of Justice, Principles of Togetherness, Principle of Independence, and Principles of Volunteerism.

The principle of equality means that in an agreement the parties have the same degree and bargaining position. With this principle it is expected that the parties that partner have a balanced bargaining position. Partnership agreements also may not incriminate one party or even harm another party. According to Mariam Darus Badrulzaman (Badrulzaman, 2001). In contract law there is an unconscionability doctrine which teaches that a contract is canceled or can be canceled by the injured party when there is an unfair clause and is very burdensome for one party, even though one party has signed the contract. The principle of togetherness must be the main foundation in a partnership agreement because all business groups must advance and grow together in accordance with their respective capacities and roles. Partnership is essentially not an obligation for every company, the partnership was born from a sense of corporate social responsibility for the environment, the community, and the surrounding business groups.

The general principles and conditions of the agreement must also be material reference in the practice of partnership. Government Regulation No. 47 of 1997 concerning Partnership, in general has set the rights and obligations of the parties to the partnership and stressed the need to make a written agreement that at least contains the name, place of residence of each party the form and scope of business being partnered, the partnership pattern used, rights and the obligations of each party, the period of validity of the agreement, the method of payment, the form of guidance provided by Large and Medium Enterprises, and the procedure for resolving disputes. However, bearing in mind that the legal umbrella of partnership itself still has some weaknesses, and the intensity of assistance and supervision is also inadequate, as a result there are still many unfair partnerships in practice that tend to harm either party. So efforts to apply the principles and principles of the agreement in a business partnership can be included in the sub-contract bill, the Small and Medium Enterprise Development Bill (UKM), or in the revision of the legislation regarding the partnership itself if possible.

\section{Application of the principles of agreement in partnership that can provide protection for SMEs in Indonesia}

One of the central problems in relation to legal protection efforts in partnership agreements is Government Regulation No. 44 About Partnership does not explicitly mention legal aid institutions as supporting institutions for implementing partnerships. Even though this institution is very important in the context of legal protection of the parties since the negotiation period of the agreement, the stage of production, to post-production, including the issue of IPR for small businesses, a matter that gets special attention in the TRIPs-WTO Agreement, especially the national treatment and the principle of nondiscrimination (Ramli, 2000).

Government Regulation No. 44 of 1997 concerning Partnerships does not explicitly emphasize the existence of equality and equal position of the parties to the partnership. In the business partnership practice so far, the position of the parties is not in an equal and balanced position, the UKM group is in the subordinate position of the medium / large business group. In this situation, it is very possible that there are various excesses which lead to the exploitation of SME groups by Large Business groups. Law 
No. 20 of 2008 concerning Micro, Small and Medium Enterprises also has weaknesses because it has a different understanding of partnership with Government Regulation No. 44 about partnerships. Understanding of Partnership according to Law No.20 of 2008 concerning Micro, Small and Medium Enterprises no longer contains elements of coaching and development by medium-sized businesses and / or large businesses as stated in the definition of partnership in Article 1 paragraph (1) of Government Regulation No. 44 About Partnerships.

Business Partnership is one of the efforts to protect SMEs, through SME partnerships being given certain facilities and privileges to be able to work with large business groups. The partnership agreement is also on the one hand an effort to protect SMEs from monopolistic or oligopolistic tendencies that can harm SMEs while preparing SMEs to deal with free market mechanisms through learning processes (outsourcigng) to Large Business Groups. Legal protection in partnership is a long process that begins at the time of pre-contract (before making the agreement) until the post-production activities, so that at each stage of the partnership there are no irregularities and can run as desired. In other words, legal protection in partnerships is carried out in accordance with the stages of the partnership itself.

In the pre-contract stage, SMEs require assistance and supervision of the preparation of a draft agreement that is in accordance with Article 18 paragraph (1) of Government Regulation No. 44 Concerning Partnership and based on the principles and principles of contract law as explained previously. At the stage of partnership work (production process), it is necessary to monitor the implementation of the agreed agreement material, including monitoring the implementation of the Development Partner's obligations in terms of fostering aspects of human resources, capital aspects, management aspects, marketing aspects as well as technological aspects in accordance with Article 29 of the Law -Number No. 9 of 1995 concerning Jo's Small Business Article 16 Government Regulation No. 44 of 1997 concerning partnerships.

In the post-production stage, monitoring of the implementation of the Fostered Partner's obligations in terms of the agreed sale of goods / commodities along with supervision of the quality standards and purchase price from the Fostering Partner is in accordance with the agreement. Monitoring work at each of these stages is basically an obligation and right attached to the parties to the partnership, because it is part of the implementation of the partnership agreement. In this case, the role of the government through its power and institutions has the obligation to oversee the implementation of partnerships so that the interests of the partners can be protected.

Monitoring and protection work can also be broadly categorized into 2 patterns, namely preventive and comprehensive. Preventive protection is carried out in the context of: (1) preparing legal and policy signs relating to business partnerships, (2) creating a conducive business climate for business partnerships in accordance with Article 10 of Government Regulation No. 44 of 1997 concerning Partnerships, and (3) coaching work in accordance with Article 22 of Government Regulation No. 44 of 1997 concerning partnerships. Repressively means protection is carried out in order to provide a solution or provide legal assistance (advocacy) when facing problems relating to the implementation of the contents of the partnership agreement.

For the government, the partnership agreement must be based solely on the ideal motivation to realize structural changes in the economic sector which are marked by structural changes in the economic field which are marked by the transformation from inequality into a balance between the existing economic forces, and the establishment of mutual ties. support and need between SME groups and Large Enterprises. For those who partner, especially large groups, the partnership must be born from a sense of corporate social responsibility towards the environment, the community and the surrounding business groups. Partnerships must be understood as strategic solutions and demands of the business climate in the global era, because in this era the business climate is dominated by a network work culture, and to be able to compete in the global market, partnership relationships are needed both vertically and horizontally.

To supervise in a business partnership agreement, SMEs are required to increase their capacity, both in terms of business management and in technical matters of production. In this way, SMEs can gradually increase their bargaining position in front of Large Business groups, so that they can equally control and supervise the business partnership. 


\section{IV.CONCLUSION}

Based on the explanation above, thus it can be concluded that 1) the partnership agreement model between SMEs and Large Enterprises in creating shared prosperity must begin with efforts to apply the principles of the agreement and business ethics in the partnership agreement. 2) The application of the principles of agreement in partnership in practice has not yet run optimally, there are still many partnership agreements that have been deviated from the contents of the agreement. In this case the role of government is needed to provide protection to the SME group and also the Large Business group to realize social responsibility for the progress of the UKM business group.

\section{REFERENCES}

Badrulzaman, M. D. (2001). Kompilasi Hukum Perikatan. Bandung: Citra Aditya Bakti.

Hafsah, M. J. (1999). Kemitraan Usaha: Konsep dan Strategi. Jakarta: Pustaka Sinar Harapan.

Khairandy, R. (2004). Itikad Baik Dalam Kebebasan Berkontrak. Fakultas Hukum Universitas Indonesia.

Mubyarto. (2001). Prospek Otonomi Daerah dan Perekonomian Indonesia Pasca Krisis Ekonomi. Jurnal Ekonomi Dan Bisnis Indonesia, 16(2), 199-205. Retrieved from https:/jurnal.ugm.ac.id/jieb/article/ download/40010/22554

Mulhadi, \& Sembiring, Z. (2019). Legal Characters of Partnership Agreement 212 Mart. Jurnal Cita Hukum, 7(2). Retrieved from https://doi.org/10.15408/jch.v7i2.9591

Nugroho, A., Sulistyowati, E., \& Hikmah, N. (2017). A juridical review of partnership agreements that have the elements of work agreements in Indonesia. The 2nd International Joint Conference on Science and Technology (IJCST), 1-6. Retrieved from https://iopscience.iop.org/article/10.1088/17426596/953/1/012169/pdf

Ramli, A. M. (2000). Hak Atas Kepemilikan Intelektual, Teori Dasar Perlindungan Rahasia Dagang. Retrieved from https://opac.perpusnas.go.id/DetailOpac.aspx?id=282339

Satrio, J. (2001). Hukum Perikatan, Perikatan Yang lahir Dari Perjanjian Buku I. Bandung: Citra Aditya Bakti.

Soekanto, S., \& Mamudji, S. (1995). Penelitian Hukum Normatif, Suatu Tinjauan Singkat. Jakarta: PT Raja Grafindo Persada.

Soemitro, R. H. (1980). Metodologi Penelitian Hukum dan Jurimetri. Jakarta: Ghalia Indonesia.

Subekti. (1984). Pokok-Pokok Hukum Perdata. Jakarta: Intermasa. 